\title{
Intensified biocatalytic production of enantiomerically pure halophenylalanines from acrylic acids using ammonium carbamate as the ammonia source
}

DOI:

10.1039/C6CY00855K

\section{Document Version \\ Accepted author manuscript}

Link to publication record in Manchester Research Explorer

Citation for published version (APA):

Weise, N., Ahmed, S., Parmeggiani, F., Siirola, E., Pushpanath, A., Schell, U., \& Turner, N. (2016). Intensified biocatalytic production of enantiomerically pure halophenylalanines from acrylic acids using ammonium carbamate as the ammonia source. Catalysis Science and Technology, 6(12), 4086-4089.

https://doi.org/10.1039/C6CY00855K

\section{Published in:}

Catalysis Science and Technology

\section{Citing this paper}

Please note that where the full-text provided on Manchester Research Explorer is the Author Accepted Manuscript or Proof version this may differ from the final Published version. If citing, it is advised that you check and use the publisher's definitive version.

\section{General rights}

Copyright and moral rights for the publications made accessible in the Research Explorer are retained by the authors and/or other copyright owners and it is a condition of accessing publications that users recognise and abide by the legal requirements associated with these rights.

\section{Takedown policy}

If you believe that this document breaches copyright please refer to the University of Manchester's Takedown Procedures [http://man.ac.uk/04Y6Bo] or contact uml.scholarlycommunications@manchester.ac.uk providing relevant details, so we can investigate your claim.

\section{OPEN ACCESS}




\section{Accepted Manuscript}

This article can be cited before page numbers have been issued, to do this please use: N. J. Weise, S. T. Ahmed, F. Parmeggiani, E. Siirola, A. Pushpanath, U. Schell and N. J. Turner, Catal. Sci. Technol., 2016,

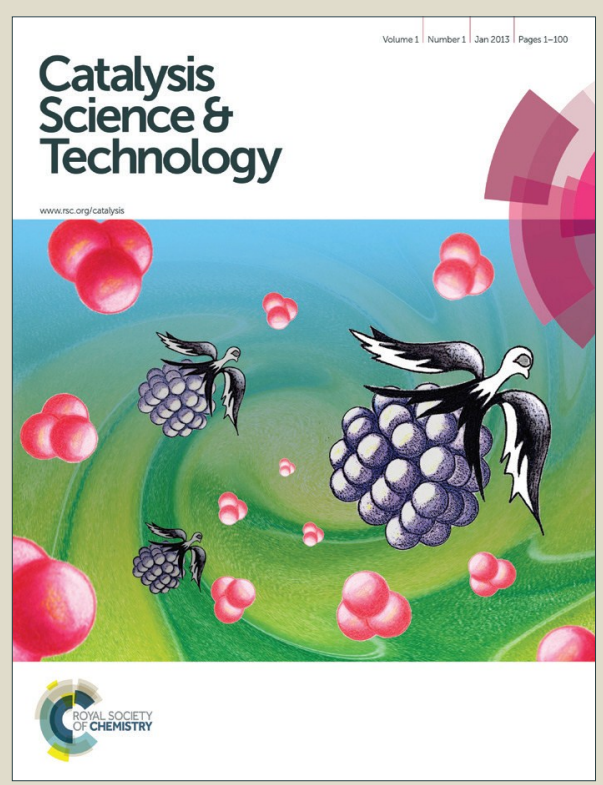

This is an Accepted Manuscript, which has been through the Royal Society of Chemistry peer review process and has been accepted for publication.

Accepted Manuscripts are published online shortly after acceptance, before technical editing, formatting and proof reading. Using this free service, authors can make their results available to the community, in citable form, before we publish the edited article. We will replace this Accepted Manuscript with the edited and formatted Advance Article as soon as it is available.

You can find more information about Accepted Manuscripts in the Information for Authors.

Please note that technical editing may introduce minor changes to the text and/or graphics, which may alter content. The journal's standard Terms \& Conditions and the Ethical guidelines still apply. In no event shall the Royal Society of Chemistry be held responsible for any errors or omissions in this Accepted Manuscript or any consequences arising from the use of any information it contains. 


\section{Catalysis Science \& Technology}

Received 00th January 20xx, Accepted 00th January 20xx

DOI: $10.1039 / x 0 x \times 00000 x$

www.rsc.org/

\section{Intensified Biocatalytic Production of Enantiomerically Pure Halophenylalanines from Acrylic Acids Using Ammonium Carbamate as the Ammonia Source ${ }^{\dagger}$}

Nicholas J. Weise, ${ }^{a}$ Syed T. Ahmed, ${ }^{\text {a }}$ Fabio Parmeggiani, ${ }^{a}$ Elina Siirola, ${ }^{b}$ Ahir Pushpanath, ${ }^{b}$ Ursula Schell ${ }^{b}$ and Nicholas J. Turner*,a

An intensified, industrially-relevant strategy for the production of enantiopure halophenylalanines has been developed using the novel combination of a cyanobacterial phenylalanine ammonia lyase (PAL) and ammonium carbamate reaction buffer. The process boasts STYs up to $>200 \mathrm{~g} \mathrm{~L}^{-1} \mathrm{~d}^{-1}$, ees $\geq 98 \%$ and simplified catalyst / reaction buffer preparation and work up.

Ring-halogenated phenylalanine analogues are a class of unnatural amino acids used in variety of research endeavours in medicinal chemistry and chemical biology. Compounds such as 3-fluoro-Lphenylalanine, for example, have been identified as key components of antifungal di- and tripeptides, effective against multidrug-resistant strains of the opportunistic human pathogen Candida albicans. ${ }^{1}$ This same molecule, along with its 4-fluoro regioisomer, has been shown to improve the catalytic properties of lipase under industrially-relevant conditions via incorporation into the polypeptide in lieu of natural proteinogenic amino acids. ${ }^{2}$ In a similar vein, genetic incorporation of para-halo-L-phenylalanines into a maltose binding protein is reported to enable site-specific tagging following Suzuki-Miyaura coupling with a furanylboronic acid. $^{3}$ This coupling method can also be used to functionalise bromo- and chloro- phenylalanine derivatives to create drug molecules such as the biaryl dipeptidyl peptidase IV inhibitors, novel candidates for the management of type II diabetes. ${ }^{4,5}$

The use of enzymes to carry out highly chemo-, regio- and enantioselective syntheses is an attractive strategy in terms of minimising the environmental impact (e.g. from side product generation, protection/deprotection steps) of chemical processes. This is due to their ability to mediate challenging reactions under mild aqueous conditions, reducing both energy input and organic solvent waste. Enzyme catalysts are built from natural primary

\footnotetext{
a. Manchester Institute of Biotechnology \& School of Chemistry, University of Manchester, 131 Princess Street, M1 7DN, Manchester, UK.

b. Johnson Matthey Catalysts and Chiral Technologies, 28 Cambridge Science Park, Milton Road, CB4 OFP, Cambridge, UK.

+Electronic Supplementary Information (ESI) available: biotransformation optimisation, analytical methods and characterisation data. See DOI: $10.1039 / \mathrm{x} 0 \times x \times 0000 \mathrm{x}$
}

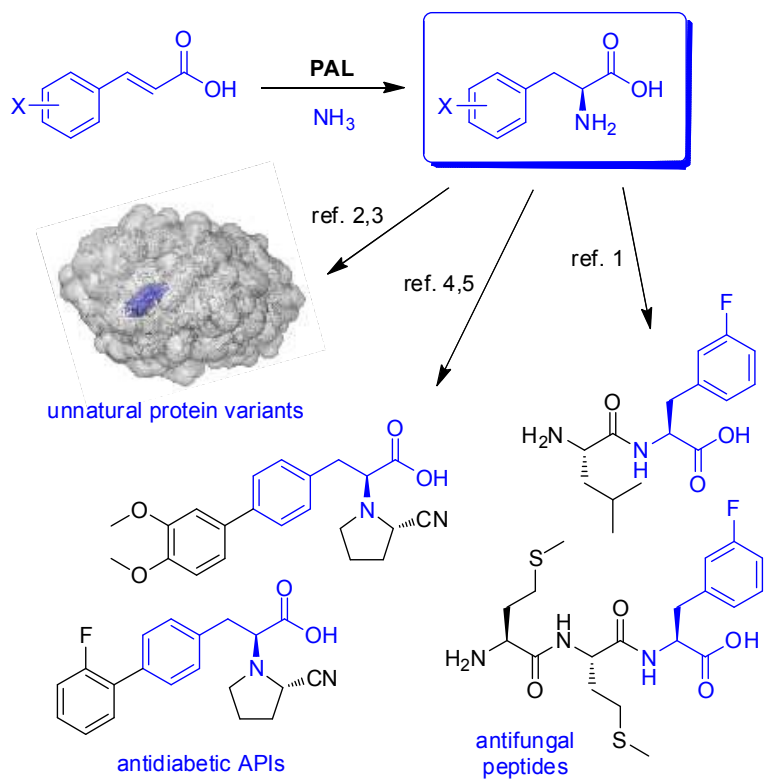

Scheme 1. Phenylalanine ammonia lyase ( $P A L)$ as a strategy for the production of halophenylalanines for use in the creation of tailored proteins and pharmaceuticals.

metabolites in a renewable manner using facile recombinant DNA technologies. Biocatalysts with a well characterised ability to produce halogenated arylalanines are the phenylalanine ammonia lyase (PAL) enzymes, which allow the selective addition of free ammonia to inexpensive and readily-available cinnamic acid derivatives. ${ }^{4,6-11}$ This process is $100 \%$ atom efficient, relying solely on a catalytic tyrosine and the 4-methylideneimidazole-5-one (MIO) prosthesis, thus mitigating the need for expensive and wasteful cofactor supplementation / regeneration. Due to the unique chemistry, difficult to mimic with traditional synthetic methods, PALs have been used in the synthesis of the pharmaceutical intermediates 4-bromo- ${ }^{4}$ and 2-chloro-L-phenylalanine. ${ }^{9,12}$ The latter process - used in the industrial-scale production of the antihypertension drug perindopril - is a rare example of an intensified reaction, with a space-time yield (STY) of $51.2 \mathrm{~g} \mathrm{~L}^{-1} \mathrm{~d}^{-1} .12$ 
Despite the utility of halophenylalanines and the demonstrated efficiency of PAL-catalysed reactions, ${ }^{6,7,10}$ there exist very few examples of large scale syntheses of these compounds using this method. Herein we report a superior intensified method for the preparative scale amination of readily-accessible halocinnamates to give enantiopure amino acids in good purity with a chromatography-free workup, employing a novel ammonia source. Previous studies with ammonia lyase biocatalysts revealed that they suffer from inactivation and can require lengthy formulation procedures for effective use. ${ }^{13,14}$ In the interests of simplifying catalyst preparation, the previously characterised enzyme from the cyanobacterium Anabaena variabilis (AvPAL) ${ }^{15}$ was used due to its demonstrated thermostability ${ }^{16}$ and conversion of diverse cinnamate derivatives. ${ }^{8-10}$ Through various optimisation steps, a method was arrived at by which $150 \mathrm{mM}$ 3-fluorocinnamic acid $\mathbf{1 b}$ could be converted to $93 \%$ (details of the optimisation steps are reported in the ESI). These reaction parameters were: $20 \mathrm{mg} \mathrm{mL}^{-1}$ lyophilised Escherichia coli whole cells harbouring the AvPAL biocatalyst, $13 \% \mathrm{w} / \mathrm{v}$ ammonia solution $\mathrm{pH}$ adjusted with carbon dioxide ( $\mathrm{pH} 9.5$ ), $30^{\circ} \mathrm{C}, 200 \mathrm{rpm}, 22 \mathrm{~h}$. Despite the improvements in reaction parameters, the method did, however, require a large quantity of $\mathrm{CO}_{2}$ to form an ammonium carbonate solution of sufficient concentration and $\mathrm{pH}$. As this would constitute a major problem and increase costs in an industrial setting, an alternative ammonia source was sought for further investigations.

Use of ammonium carbamate was considered due to its high solubility, volatility, low cost and unbuffered $\mathrm{pH} \sim 10$. As an initial test, a $150 \mathrm{mM}$ amination reaction of 3-fluorocinnamic acid $\mathbf{1} \mathbf{b}$ was conducted with $4 \mathrm{M}$ ammonium carbamate, affording $98 \%$ conversion within a $22 \mathrm{~h}$ time period indicating both an increase in reaction productivity and a shift in equilibrium. Similar improvements have been observed with different biocatalytic systems ${ }^{17}$ and may be due to the potential of the carbamate counter-ion to act as a slow release source of additional ammonia, providing more of this reactant. The effect of substrate loading with this new system was tested with solutions of 50-350 mM substrate (Table 1) and it was found that, even up to $300 \mathrm{mM}$ substrate concentration, $\geq 97 \%$ conversion could be obtained (dropping to $81 \%$ at $350 \mathrm{mM}$ ). All conversions were calculated from combined soluble and insoluble fractions of the reaction mixture, since the substrate was found not to be fully soluble at concentrations $>200$ $\mathrm{mM}$.

In light of the efficiency conferred by the new reaction buffer, preparative scale $(4 \mathrm{~mL})$ reactions were set up with a variety of cinnamic acid derivatives (1a-i, Table 2), previously reported to be substrates for AvPAL. In each case, reaction parameters were altered so as to allow $>95 \%$ conversion with the $4 \mathrm{M}$ ammonium carbamate and $20 \mathrm{mg} \mathrm{mL}^{-1}$ catalyst at $30^{\circ} \mathrm{C}$. It was observed that, for fluorinated compounds (1a-c, $\mathbf{g}$ and h) $100 \mathrm{mM}$ substrate concentration was sufficient, while for the less soluble substrates (such as the chloro-substituted $\mathbf{1} \mathbf{d}-\mathbf{f}$ and $\mathbf{i}$ ), concentrations of 50 $\mathrm{mM}$ were more appropriate. In each set of compounds the least soluble para-isomer seemed to give less than the desired conversion after 1 day - a situation remedied by additional
Table 1. Effect of varying substrate concentration on intensified,small-scale aminations of $\mathbf{1 b}$ by AvPAL.

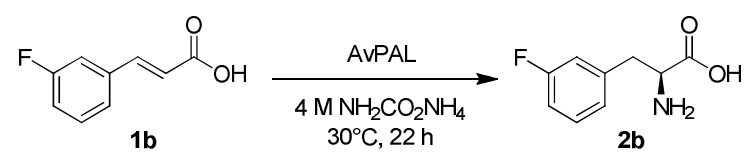

\begin{tabular}{cccc}
\hline $\begin{array}{c}\text { Substrate conc. } \\
\text { [mM] }\end{array}$ & $\begin{array}{c}\text { Conv. } \\
{[\%]}\end{array}$ & $\begin{array}{c}\text { ee of } \mathbf{2 b} \\
{[\%]}\end{array}$ & $\begin{array}{c}\text { Theoretical STY } \\
{\left[\mathbf{g ~ L}^{-\mathbf{1}} \mathbf{d}^{\mathbf{- 1}} \text { ] }\right.}\end{array}$ \\
\hline 50 & $>99$ & $>99(S)$ & $\sim 9$ \\
100 & 99 & $>99(S)$ & $\sim 18$ \\
150 & 98 & $99(S)$ & $\sim 26$ \\
200 & 98 & $99(S)$ & $\sim 34$ \\
250 & 97 & $98(S)$ & $\sim 43$ \\
300 & 97 & $98(S)$ & $\sim 51$ \\
350 & 81 & $98(S)$ & $\sim 50$ \\
\end{tabular}

incubation time to achieve $>95 \%$ conversion. The apparent exception to this observation was the 3,4-difluorocinnamate $\mathbf{1 g}$ which, despite having a para-fluoro group, was already found to give $97 \%$ conversion within 24 hours. In all cases the (S)-enantiomer of $\mathbf{2}$ was produced with excellent stereoselectivity, with ee values of $98 \%$ or above being achieved. Given the reasonable STY values achieved (4.7-19.5 $\mathrm{g} \mathrm{L}^{-1} \mathrm{~d}^{-1}$ ) all products could be isolated by centrifugation to remove the whole cell catalyst and evaporation of the volatile reaction buffer, with no need for further purification. NMR analyses of the remaining quantitative crude isolate (see ESI) reflected the purity of the product as previously estimated by HPLC.

As a demonstration of the industrial viability of our method, a gram-scale synthesis of (S)-2b as a model target product was

Table 2. Optimisation of reaction parameters to give $>95 \%$ conversion of a panel of halocinnamates 1a-i in AvPAL-catalysed biotransformations.

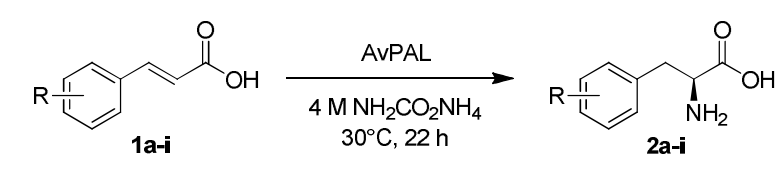

\begin{tabular}{llccccc}
\hline $\mathbf{1}$ & $\mathbf{R}$ & $\begin{array}{c}\text { Subs. conc. } \\
{[\mathbf{m M}]}\end{array}$ & $\begin{array}{c}\text { Time } \\
{[\mathbf{h}]}\end{array}$ & $\begin{array}{c}\text { Conv. } \\
{[\%]}\end{array}$ & $\begin{array}{c}\text { ee of } \mathbf{2 b} \\
{[\%]}\end{array}$ & $\begin{array}{c}\text { STY } \\
{\left[\mathrm{g} \mathrm{L}^{-1} \mathbf{d}^{-1}\right]}\end{array}$ \\
\hline $\mathbf{1 a}$ & $2-\mathrm{F}$ & 100 & 24 & $>99$ & $>99(S)$ & 18.3 \\
$\mathbf{1 b}$ & $3-\mathrm{F}$ & 100 & 24 & 99 & $>99(S)$ & 18.1 \\
$\mathbf{1 c}$ & $4-\mathrm{F}$ & 100 & 48 & 96 & $99(S)$ & 8.8 \\
$\mathbf{1 d}$ & $2-\mathrm{Cl}$ & 50 & 24 & $>99$ & $>99(S)$ & 10.0 \\
$\mathbf{1 e}$ & $3-\mathrm{Cl}$ & 50 & 48 & 96 & $98(S)$ & 4.8 \\
$\mathbf{1 f}$ & $4-\mathrm{Cl}$ & 50 & 48 & 95 & $98(S)$ & 4.7 \\
$\mathbf{1 g}$ & $3,4-\mathrm{F}_{2}$ & 100 & 24 & 97 & $99(S)$ & 19.5 \\
$\mathbf{1 h}$ & $2-\mathrm{Cl}-4-\mathrm{F}$ & 100 & 48 & 96 & $99(S)$ & 10.4 \\
$\mathbf{1 i}$ & $2,6-\mathrm{Cl}_{2}$ & 50 & 24 & 96 & $>99(S)$ & 11.2 \\
\hline
\end{tabular}


optimised, in order to find a balance between high conversion and space-time yield (see ESI). The final reaction procedure simply required addition of $5.3 \mathrm{~g}$ ammonium carbamate, $1 \mathrm{~g}$ 3fluorocinnamate and $1 \mathrm{~g}$ dried whole cell catalyst powder to $17 \mathrm{~mL}$ deionized water under stirring $(200 \mathrm{rpm})$ at $30^{\circ} \mathrm{C}$. After a 6 hour reaction time a sample of the reaction was taken and analysed, revealing a conversion of $92 \%$ to (S)-2b (ee $99 \%$ ). This value equated to approximately $1 \mathrm{~g}$ amino acid being produced, giving a theoretical space-time yield of $237.6 \mathrm{~g} \mathrm{~L}^{-1} \mathrm{~d}^{-1}$ - a value much higher than existing industrial scale synthesis of a pharmaceutical intermediate using a related PAL. ${ }^{12}$ The process presented here also features higher catalyst productivity, a lack of requirement for batch addition of substrate or catalyst and ready availability of the volatile ammonium donor salt, without the need for $\mathrm{pH}$ adjustment or lengthy ion-exchange work-up methods. The environmental factor (E factor) of the reaction is also calculated to be $\sim 5$, which is far lower than the typical values for fine chemical synthesis, an improvement on other PAL-mediated reactions and borderline for bulk chemical production. ${ }^{18}$

This improved protocol proved also to be compatible with our recently reported telescopic combination of cinnamic acid synthesis and PAL hydroamination. ${ }^{19}$ The Knoevenagel-Doebner condensation of 3-fluorobenzaldehyde $\mathbf{3}$ and malonic acid was performed under optimised conditions. The crude reaction mixture $(\sim 1 \quad M$ concentration of $\mathbf{1 b}$ ) was then used directly as starting material for subsequent biotransformation reactions. Different volume ratios of the reaction mixture and ammonium carbamate solution were

Table 3. Comparison of our intensified PAL-mediated gram-scale synthesis of $\mathbf{2} \mathbf{b}$ with the best reported industrial method.

\begin{tabular}{|c|c|c|}
\hline Method & $\mathrm{DSM}^{12}$ & This work \\
\hline Catalyst & undisclosed PAL & $\begin{array}{c}\text { PAL from Anabaena } \\
\text { variabilis }\end{array}$ \\
\hline $\begin{array}{l}\text { Catalyst } \\
\text { productivity }\end{array}$ & $\begin{array}{l}0.14 \mathrm{~g} \mathrm{~g}^{-1} \text { (wet whole } \\
\text { cells) }\end{array}$ & $\begin{array}{c}1 \mathrm{~g} \mathrm{~g}^{-1} \text { (dry whole } \\
\text { cells) }\end{array}$ \\
\hline Substrate conc. & $\begin{array}{c}100 \mathrm{mM} \text { ( } 20 \times 5 \mathrm{mM} \\
\text { batch additions) }\end{array}$ & $354 \mathrm{mM}$ \\
\hline $\begin{array}{l}\text { Reaction } \\
\text { conditions }\end{array}$ & $\begin{array}{c}1 \mathrm{~L}, 30^{\circ} \mathrm{C}, \mathrm{pH} 11.0 \\
200 \mathrm{rpm}\end{array}$ & $\begin{array}{c}17 \mathrm{~mL}, 30^{\circ} \mathrm{C}, \mathrm{pH} 9.9, \\
200 \mathrm{rpm}\end{array}$ \\
\hline Time & $8.5 \mathrm{~h}$ & $6 \mathrm{~h}$ \\
\hline $\begin{array}{l}\text { Conv. (Product } \\
\text { conc.) }\end{array}$ & $91 \%$ (91 mM) & $92 \%(326 \mathrm{mM})$ \\
\hline STY & $51.2 \mathrm{~g} \mathrm{~L}^{-1} \mathrm{~d}^{-1}$ & $237.6 \mathrm{~g} \mathrm{~L}^{-1} \mathrm{~d}^{-1}$ \\
\hline E factor ${ }^{a}$ & $7.14(54.0)$ & $5.30(22.3)$ \\
\hline
\end{tabular}

a The $E$ factor values in brackets include waste water in the calculation.

combined before addition of $20 \mathrm{mg} \mathrm{mL}^{-1}$ catalyst (Table 4). Conversions to $(S)-\mathbf{2} \mathbf{b}$ were found to be slightly lower than (but comparable to) the corresponding reactions with pure $\mathbf{1 b}$, with equally excellent ee values. The lowered conversions are likely due to the increased concentration of DMSO from the initial chemical reaction, shown previously to be mildly inhibitory to the AvPAL reaction. ${ }^{19}$ This result constitutes an improvement of this extended approach to amino acid synthesis, allowing greater telescopic loading of the first reaction mixture into a more intensified hydroamination to yield the final product, thus incurring less overall waste from the biocatalytic step.

Table 4. Telescopic synthesis of $\mathbf{2} \mathbf{b}$ from the corresponding benzaldehyde $\mathbf{3}$ via Knoevenagel-Doebner condensation and subsequent PAL-mediated ammonia addition.

\begin{tabular}{|c|c|c|c|}
\hline 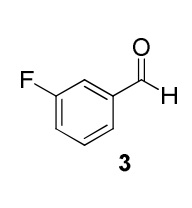 & 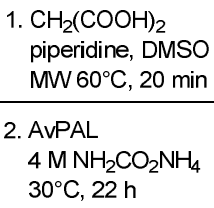 & 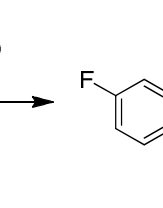 & \\
\hline $\begin{array}{c}\text { Volume ratio }^{a} \\
{[\% \mathrm{v} / \mathrm{v}]}\end{array}$ & $\begin{array}{l}\text { Substrate } \\
\text { conc. } \\
\text { [mM] }\end{array}$ & $\begin{array}{c}\text { Overall conv. } \\
\text { [\%] }\end{array}$ & $\begin{array}{c}\text { ee of } \mathbf{2 b} \\
{[\%]}\end{array}$ \\
\hline 10 & $\sim 100$ & 95 & $99(S)$ \\
\hline 20 & 200 & 93 & $99(S)$ \\
\hline 30 & $\sim 300$ & 83 & $>99(S)$ \\
\hline
\end{tabular}

a Percentage by volume of the crude condensation mixture added to the carbamate solution containing PAL.

Furthermore, our intensified biotransformation process was also applied to the synthesis of the pharmaceutical building block biarylalanine $\mathbf{4}$ starting from 3-bromocinnamic acid $\mathbf{1 j}$ (Scheme 2). The chemo-enzymatic approach combining PAL-mediated hydroamination with Suzuki-Miyaura coupling was previously employed for the synthesis of 4 -aryl substituted phenylalanines, ${ }^{4}$ but this process required an ion exchange chromatography step to remove the high concentration of ammonium sulphate and unreacted cinnamic acid substrate. The downstream process could be considerably mitigated by adopting ammonium carbamate under optimised conditions: almost full conversion (96\%) of $\mathbf{1 j}$ to (S)-2 j was achieved, leaving a negligible amount of starting material (ESI). The crude product obtained after removal of ammonium carbamate by sublimation could be used without further treatment for $\mathrm{N}$-protection followed by Suzuki-Miyaura coupling, ${ }^{4}$ affording 4 in $24 \%$ overall isolated yield from $\mathbf{1 j}$ (Scheme 2). The structural moiety of 3-aryl substituted phenylalanine is present in several pharmaceutical ingredients and building blocks, such as selective $N$ methyl-D-aspartate receptor (NMDA) antagonists for treatment of Parkinson's disease, ${ }^{20,21}$ angiotensin-converting enzyme 2 (ACE-2) modulators for weight disorders ${ }^{22}$ and chemotactic peptides. ${ }^{23}$

In conclusion, an improved and simplified method for the production of various halogenated amino acids in excellent enantiomeric excess has been reported. The catalyst of choice is a recombinant, stable wild-type PAL produced from renewable feedstocks, harboured within lyophilised whole cells to mitigate lengthy catalyst purification and/or immobilisation steps. 


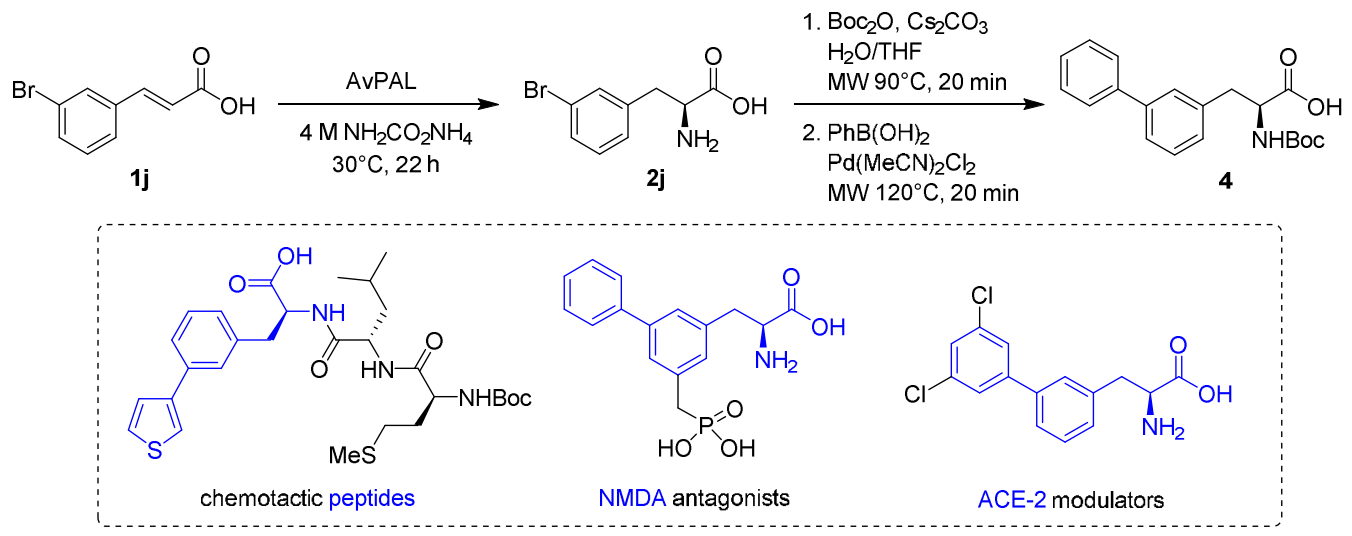

Scheme 2. Chemo-enzymatic strategy for the synthesis of biarylalanine $\mathbf{4}$ from $\mathbf{1 j}$, consisting of PAL amination, $\mathrm{N}$-protection and SuzukiMiyaura coupling. Examples of pharmaceutical ingredients or candidates containing the substructure of 4 are shown in blue.

The $100 \%$ atom efficient synthesis has been achieved on a commercially-relevant scale - a considerable improvement on current industrial methods. The use of cheap, raw ammonium carbamate as a high-concentration ammonia donor salt lessens the work associated with producing high molarity, $\mathrm{pH}$ adjusted buffers and allows the equilibrium of the reaction to be driven towards product formation, due to its high solubility and ammonia content. The nature of the reaction mixture, combined with the optimised conversions (>95\%) allow easy crude isolation of the amino acid products to a good level of purity - sufficient to enable easy modular integration with further chemical steps.

\section{Acknowledgements}

This work was funded by the European Union's $7^{\text {th }}$ Framework program FP7/2007-2013 under grant agreement no. 289646 (KYROBIO). F. P. and S. T. A. were supported by the Biotechnology and Biological Sciences Research Council (BBSRC) and GlaxoSmithKline (GSK) under the Strategic Longer and Larger (sLoLa) grant initiative ref. BB/K00199X/1. We thank the Royal Society for a Wolfson Research Merit Award (N. J. T.)

\section{Notes and references}

1 R. Wakiec, I. Gabriel, R. Prasad, J. M. Becker, J. W. Payne and S. Milewski, Antimicrob. Agents Chemother., 2008, 52, 4057-4063.

2 C. G. Acevedo-Rocha, M. G. Hoesl, S. Nehring, M. Royter, C. Wolschner, B. Wiltschi, G. Antranikian and N. Budisa, Catal. Sci. Technol., 2013, 3, 1198-1201.

3 C. D. Spicer and B. G. Davis, Chem. Commun., 2011, 47, 1698-1700.

4 S. T. Ahmed, F. Parmeggiani, N. J. Weise, S. L. Flitsch and N. J. Turner, ACS Catal., 2015, 5, 5410-5413.

5 L. Qiao, C. a Baumann, C. S. Crysler, N. S. Ninan, M. C. Abad, J. C. Spurlino, R. L. Desjarlais, J. Kervinen, M. P. Neeper, S. S. Bayoumy, R. Williams, I. C. Deckman, M.
Dasgupta, R. L. Reed, N. D. Huebert, B. E. Tomczuk and K. J. Moriarty, Bioorg. Med. Chem. Lett., 2006, 16, 123-128.

6 A. Gloge, J. Zoń, A. Kövári, L. Poppe and J. Rétey, Chem. Eur. J., 2000, 6, 3386-3390.

7 S. Bartsch and U. T. Bornscheuer, Protein Eng. Des. Sel., 2010, 23, 929-933.

8 S. L. Lovelock, R. C. Lloyd and N. J. Turner, Angew. Chem. Int. Ed., 2014, 53, 4652-4656.

9 S. L. Lovelock and N. J. Turner, Bioorg. Med. Chem., 2014, 22, 5555-5557.

10 F. Parmeggiani, S. L. Lovelock, N. J. Weise, S. T. Ahmed and N. J. Turner, Angew. Chem. Int. Ed. Engl., 2015, 54, 46084611.

11 N. J. Weise, F. Parmeggiani, S. T. Ahmed and N. J. Turner, J. Am. Chem. Soc., 2015, 137, 12977-12983.

12 B. de Lange, D. J. Hyett, P. J. D. Maas, D. Mink, F. B. J. van Assema, N. Sereinig, A. H. M. de Vries and J. G. de Vries, ChemCatChem, 2011, 3, 289-292.

13 D. G. Rees and D. H. Jones, Enzyme Microb. Technol., 1996, 819, 282-288.

14 J. D. Cui, S. Zhang and L. M. Sun, Appl. Biochem. Biotechnol., 2012, 167, 835-844.

15 M. C. Moffitt, G. V Louie, M. E. Bowman, J. Pence, P. Joseph and B. S. Moore, Biochemistry, 2008, 46, 10041012.

16 L. Wang, A. Gamez, H. Archer, E. E. Abola, C. N. Sarkissian, P. Fitzpatrick, D. Wendt, Y. Zhang, M. Vellard, J. Bliesath, J. Lemont, C. R. Scriver and R. C. Stevens, J. Mol. Biol., 2009, 380, 623-635.

M. J. J. Litjens, A. J. J. Straathof, J. A. Jongejan and J. J. Heijnen, Chem. Commun., 1999, 1255-1256.

R. A. Sheldon, Green Chem., 2007, 9, 1273-1283.

F. Parmeggiani, S. T. Ahmed, N. J. Weise and N. J. Turner, Tetrahedron, In Press, DOI: 10.1016/j.tet.2015.12.063.

W. Mueller, M. Banziger and P. Kipfer, Helv. Chim. Acta, 1998, 81, 729-733.

W. Mueller, P. Kipfer, D. A. Lowe, S. Urwyler, Helv. Chim. Acta, 1995, 78, 2026-2035.

US Pat. 2004082496A1, 2004.

M. J. Burk, J. R. Lee, J. P. Martinez and N. Carolina, J. Am. Chem. Soc., 1994, 116, 10847-10848. 
